\author{
KATARZYNA ANDREJUK ${ }^{1}$ \\ Instytut Filozofii i Socjologii Polskiej Akademii Nauk \\ Ośrodek Badań nad Migracjami, Uniwersytet Warszawski
}

\title{
Jacy imigranci rejestrują się jako bezrobotni? Dynamika bezrobocia wśród cudzoziemców w $\mathrm{RP}^{2}$
}

Artykuł analizuje dane na temat cudzoziemców zarejestrowanych jako osoby bezrobotne w Polsce. Najwięcej zarejestrowanych bezrobotnych pochodzi z krajów byłego Związku Radzieckiego, w szczególności z Ukrainy, Rosji, Białorusi, Armenii. Za taki rozkład odpowiadają różne czynniki, np. Ukraińcy to największa i dynamicznie rosnąca społeczność imigrancka, więc proporcjonalnie obarczona największym ryzykiem bezrobocia. Z kolei osoby ujęte w statystykach jako Rosjanie to głównie uchodźcy z Czeczenii. Niemal nieobecni wśród zarejestrowanych bezrobotnych są imigranci z Wietnamu, Indii i Chin, mimo że społeczności z tych krajów są w Polsce relatywnie duże. Z samym statusem bezrobotnego jest związany dostęp do pewnych podstawowych świadczeń społecznych (zwłaszcza objęcie publiczną opieką zdrowotną). Natomiast udział osób z prawem do zasiłku w populacji cudzoziemców zarejestrowanych jako bezrobotni jest bardzo niski, mniejszy niż w przypadku ogółu bezrobotnych w Polsce. Ponadto analiza odsetka bezrobotnych w zależności od państwa pochodzenia wykazała, że w latach 2012-2017 udział bezrobotnych w populacji imigrantów z poszczególnych grup co do zasady zmniejszał się. Przyrost populacji imigranckiej był dużo większy niż przyrost liczby bezrobotnych. W podsumowaniu zaproponowane są wyjaśnienia niskiego poziomu bezrobocia wśród imigrantów w Polsce. Analizując bezrobocie rejestrowane imigrantów w Polsce, artykuł wypełnia ważną lukę badawczą dotyczącą analizy bierności zawodowej cudzoziemców w RP.

Słowa kluczowe: bezrobocie imigrantów, imigranci a świadczenia społeczne, hipoteza magnesu państwa dobrobytu

\footnotetext{
${ }^{1}$ Kontakt: kandrejuk@ifispan.waw.pl

${ }^{2}$ Praca powstała w ramach grantu Narodowego Centrum Nauki numer 2014/14/Z/HS4/00006.
} 


\section{What immigrants register as the unemployed? Dynamics of unemployment among foreigners in Poland}

The article analyses the data about foreigners registered as unemployed in Poland. The most numerous groups of the registered unemployed originate from the post-Soviet bloc, especially Ukraine, Russia, Belarus, Armenia. This distribution is a result of various determinants, for example Ukrainians constitute the biggest and dynamically increasing migrant community, so the numer of unemployed is proportionally higher. The individuals who have a Russian passport are usually refugees from Chechnya. The numbers of registered unemployed from Vietnam, India and China are marginal, despite the fact that these communities are relatively numerous in Poland. The sole status of unemployed is associated with the access to some basic welfare benefits (especially access to public healthcare). The share of individuals who have a right to unemployment benefit within the migrants populations is very low, lower than in case of the unemployed natives in Poland. Moreover, the analysis of the percentage of the unemployed depending on the country of origin exposed that in years 2012-2017 the share of unemployed in the migrant population often decreased. The increase in the migrant population was much higher than the increase in the number of the unemployed. The summary offers some explanations of the low level of migrant unemployment, indicating that most foreigners are labour migrants. The analysis of the registered unemployment among migrants fills in a significant gap in research about joblessness of foreigners in Poland.

Keywords: Migrant unemployment, migrants' welfare benefits intake, welfare magnet hypothesis

W ostatnich latach w wielu krajach obserwuje się wzrost negatywnych postaw wobec imigrantów. Nieufność wobec migracji oraz ludności napływowej to zjawisko dynamiczne, które również w Polsce nasilało się w ostatnim okresie. Można wyodrębnić kilka szczególnie charakterystycznych typów narracji leżących u podłoża takich podstaw. Jedna z nich to dyskurs sekurytyzacji i poczucie zagrożenia związane, np. z obcością kulturową (dystans wobec migrantów z krajów muzułmańskich). Drugim typem są narracje o cudzoziemcach zabierających miejsca pracy, a tym samym pogarszających sytuację ludności przyjmującej, wypierających pracowników rodzimych, prowadzących do obniżenia wynagrodzeń. Trzecim typem narracji są kierowane przeciw cudzoziemcom zarzuty o wykorzystywanie systemu świadczeń społecznych kraju przyjmującego, „turystykę socjalną”, czyli korzystanie z welfare danego państwa przez cudzoziemców nieaktywnych ekonomicznie. Wątki te analizowane są również w literaturze akademickiej (na temat sekurytyzacji - por. np. Williams 2003; Jędrzejczyk-Kuliniak 2017; odnośnie do cudzoziemskiej konkurencji dla pracowników rodzimych - por. Klimek 2015; na temat roli świadczeń społecznych w mobilności np.: Handlos, Kristiansen, Norredam 2016; Duszczyk, Żołędowski 2016: 290-291). Niniejszy artykuł dotyczy trzeciego typu argumentacji; ma na celu zbadanie, w jaki sposób cudzoziemcy korzystają z zasiłków dla bezrobotnych w Polsce. 
W krajach rozwiniętej wielokulturowości od dekad zwraca się uwagę na zjawisko magnesów państwa dobrobytu, czyli roli świadczeń państwa opiekuńczego w przyciąganiu imigrantów (Borjas 1999). Niektóre badania wskazują, że magnesem dla imigrantów może być wysokość świadczeń dla bezrobotnych (Giulietti et al. 2013). Z drugiej strony zauważa się, że imigranci z różnych krajów w różny sposób korzystają ze świadczeń społecznych, np. w Skandynawii bardziej skłonni do korzystania $\mathrm{z}$ welfare są cudzoziemcy z państw pozaeuropejskich oraz południowoeuropejskich, a mniej korzystają ze świadczeń cudzoziemcy z państw zachodnioeuropejskich (Hammarstedt 2009). Jak zauważa M. Hammarstedt, uchodźcy są bardziej skłonni do polegania na świadczeniach społecznych niż inne grupy, na przykład imigranci zarobkowi. Z kolei P. Kaczmarczyk zwraca uwagę na strukturę imigracji do Polski: $w$ strumieniach migracyjnych dominują osoby młode, przyjeżdżające krótkoterminowo w celu podjęcia pracy, często o charakterze sezonowym. Tacy imigranci rzadko pobierają świadczenia społeczne, zarówno z przyczyn strukturalnych (ich strategie migracyjne to przede wszystkim tymczasowa mobilność zarobkowa - model wspierany przez politykę państwa przyjmującego), jak i demograficznych (przeciętny migrant jest w sile wieku i relatywnie dobrze wykształcony) (Kaczmarczyk 2015: 33).

Znaczenie dla przyciągania imigrantów ma również narodowy model wydatkowania publicznego, czyli atrakcyjność świadczeń oferowanych przez państwa przyjmujące. Badacze instytucji państwa dobrobytu wyodrębniają różne typy narodowych polityk społecznych i „reżimów dobrobytu”. Wyróżnia się typ liberalny (USA, Kanada), korporatystyczno-państwowy (Austria, Francja, Niemcy) oraz socjaldemokratyczny (państwa skandynawskie) (Esping-Andersen 2010). Kraje Europy Środkowej, które w ostatnich dekadach doświadczyły transformacji ustrojowej, tworzą własny model państwa dobrobytu, który jest konsekwencją specyfiki ich doświadczeń historycznych i współczesnych (Fenger 2007). Cechują się one m.in. „podejściem ad hoc” do kwestii bezrobocia: $w$ tym obszarze polityki pierwotne liberalne rozwiązania zastępowano bardziej restrykcyjnymi, ograniczającymi dostęp do świadczeń, z obawy przed rozrostem bezrobocia (Deacon 2000:149). W Polsce od lat dziewięćdziesiątych XX w. mamy do czynienia z kształtowaniem się określonego stylu państwa opiekuńczego. Charakterystyczne jest to, że równolegle postępuje proces instytucjonalizacji polskiej wielokulturowości. Zwiększa się napływ imigrantów do Polski, formułowane są m.in. zasady ich dostępu do rynku pracy, ale też do różnych instytucji państwa opiekuńczego. Dotychczasowe analizy zjawiska bezrobocia w polskiej literaturze akademickiej odnoszą się do ogółu populacji kraju (np.: Pilc 2014; Dolny, Wiśniewski, Wojdyło-Preisner 2014; Kabaj 2005; Danecka 2005). Wskazuje się także na zagrożenie biernością zawodową grup marginalizowanych, takich jak niepełnosprawni (Piechota 2013) lub osoby starsze (Błędowski 2013). Analizy te koncentrują się na ludności rodzimej. Podejmując temat bezrobocia wśród imigrantów, dążę do uzupełnienia ważnej luki badawczej. 
Podstawowe pytania badawcze zadane w poniższej analizie dotyczą tego, kim są mieszkający w Polsce bezrobotni imigranci - jak różnicują się ich kraje pochodzenia oraz dostęp do świadczeń dla osób bez pracy, a także jak nasilenie rejestracji bezrobotnych cudzoziemców zmienia się na przestrzeni lat. Porządek artykułu jest następujący. Na początku przedstawię prawne uregulowania dostępu imigrantów do świadczeń dla bezrobotnych, w tym samą możliwość rejestracji cudzoziemców jako osób bezrobotnych. Następnie omówię najczęstsze grupy cudzoziemców zarejestrowanych jako bezrobotni. W kolejnej części przedstawione zostaną urzędowe dane statystyczne o bezrobotnych cudzoziemcach z prawem do zasiłku. Zaprezentuję dane na temat liczby imigrantów z wybranych państw i przeanalizuję dynamikę wielkości tych społeczności imigrantów na przestrzeni badanego okresu (2010-2017). Następnie przedstawię, na jakim poziomie kształtuje się odsetek bezrobotnych w poszczególnych grupach imigranckich, $\mathrm{z}$ uwzględnieniem zmian w ostatnich latach. Tym samym analizowane będzie nasilenie zjawiska bezrobocia w populacjach napływowych.

Zgodnie z definicją ustawy o promocji zatrudnienia i instytucjach rynku pracy, do populacji bezrobotnych wliczane są osoby pozostające bez pracy i gotowe do jej podjęcia, które zarejestrowały się w urzędzie pracy. Na tej grupie skupia się poniższa analiza i w odniesieniu do tej grupy używane jest sformułowanie „bezrobotni imigranci”. Pojęcie bezrobocia stosowane $\mathrm{w}$ artykule nie korzysta $\mathrm{z}$ definicji Międzynarodowej Organizacji Pracy, BAEL i Eurostatu, które odwołują się do sytuacji pozostawania bez pracy (niekoniecznie do bycia zarejestrowanym) jako wyznacznika bezrobocia. Bezrobocie według tego drugiego typu definicji wydaje się trudniej mierzalne. Jego poziom $\mathrm{z}$ różnych przyczyn może być inny (jak wynika $\mathrm{z}$ badań, niższy) niż poziom bezrobocia zarejestrowanego (por. Janukowicz 2010). Warto podkreślić, że korzystanie z instytucji państwa opiekuńczego może dotyczyć jedynie imigrantów zarejestrowanych jako bezrobotni, a nie wszystkich pozostających bez pracy. Artykuł analizuje dostęp migrantów do polskiego „państwa dobrobytu”, toteż wskazane jest właśnie odwołanie się do danych o bezrobociu rejestrowanym. O ile dane o bezrobociu, rozumianym jako liczba pozostających bez pracy, mogą być użyteczne z perspektywy tworzenia polityki państwa, to analiza wzorów korzystania ze świadczeń społecznych dla bezrobotnych wymaga właśnie sięgnięcia do danych o bezrobociu rejestrowanym. Podstawową metodą badawczą użytą w artykule jest analiza danych urzędowych na temat bezrobocia rejestrowanego cudzoziemców (stan na kwiecień 2017 r.). Zostały one udostępnione przez Ministerstwo Rodziny, Pracy i Polityki Społecznej na potrzeby projektu badawczego. Drugim źródłem danych są coroczne statystyki Urzędu ds. Cudzoziemców, udostępniane publicznie na stronie UDSC. 


\section{Uprawnienia cudzoziemców do rejestracji} jako osoby bezrobotne w Polsce.

\section{Jakie tytuły pobytowe umożliwiają objęcie pomocą państwa?}

Wśród cudzoziemców zarejestrowanych w urzędach pracy w Polsce można wyróżnić osoby zarejestrowane jako bezrobotne bez prawa do zasiłku oraz zarejestrowanych bezrobotnych, którym przysługuje prawo do zasiłku. Każdy z tych dwóch statusów wiąże się z pewnymi uprawnieniami, ale są one ograniczone jedynie do wybranych grup cudzoziemców.

Możliwość zarejestrowania się w Polsce jako osoby bezrobotne mają imigranci o określonych statusach pobytowych lub pochodzący z określonych państw europejskich $^{3}$. Do rejestracji w powiatowych urzędach pracy są uprawieni obywatele państw Unii Europejskiej oraz Europejskiego Obszaru Gospodarczego (Islandia, Norwegia, Lichtenstein). Wśród cudzoziemców z państwa trzecich (poza UE/ EOG), status zarejestrowanego bezrobotnego mogą uzyskać po pierwsze, osoby korzystające ze statusów związanych z przymusowym charakterem migracji. Chodzi przede wszystkim o status uchodźcy, ale też zgodę na pobyt tolerowany, zgodę na pobyt ze względów humanitarnych oraz korzystających z ochrony czasowej lub ochrony uzupełniającej. Po drugie, możliwość rejestracji jako bezrobotni mają cudzoziemcy legitymujący się trwałym tytułem pobytowym, czyli kartą stałego pobytu lub zezwoleniem na pobyt rezydenta długoterminowego Unii Europejskiej. Po trzecie, w powiatowych urzędach pracy mogą zarejestrować się osoby dysponujące zezwoleniem na pobyt czasowy $\mathrm{w}$ związku z zatrudnieniem, $\mathrm{w}$ tym również: pracą w zarządzie spółki, pracą w zawodzie wymagającym wysokich kwalifikacji, prowadzeniem badań naukowych. Aby zarejestrować się w Polsce jako bezrobotni, cudzoziemcy ci muszą legitymować się co najmniej sześciomiesięcznym okresem nieprzerwanego zatrudnienia w Polsce bezpośrednio przed rejestracją ${ }^{4}$. Warunku tego minimalnego stażu pracy nie muszą spełniać cudzoziemcy będący członkami rodzin obywateli Polski, państw UE/ EOG, którzy przybywają w celu połączenia rodziny (dołączenia do polskiego małżonka). Ta grupa nawet bez spełnienia warunku określonego stażu pracy w Polsce może się zarejestrować w urzędzie pracy. Inaczej jest w przypadku członków rodzin imigrantów z państw trzecich, którzy nie mają możliwości rejestracji jako bezrobotni w Polsce, jeśli opierają swoje zamieszkanie wyłącznie na zezwoleniu na pobyt ze względu połączenie z rodziną. Należy też podkreślić, że sformułowanie przepisów wyklucza także imigrantów, którzy przybywają do Polski do pracy sezonowej na podstawie oświadczenia o powierzeniu pracy cudzoziemcowi. Do 2018 r. (kiedy wprowadzono system zezwoleń sezonowych)

${ }^{3}$ Art. 2 ust. 1 pkt 2 ustawy z 20 kwietnia 2004 r. o promocji zatrudnienia i instytucjach rynku pracy (pziirp) w związku $\mathrm{z}$ art. 1 ust. 3 pziirp.

4 Art. 2 ust. 1 pkt 2 pziirp. 
była to najliczniejsza grupa imigrantów zarobkowych w Polsce. System oświadczeń pozwala na maksymalnie sześciomiesięczny pobyt cudzoziemca połączony z pracą.

Cudzoziemcy zarejestrowani jako bezrobotni mogą korzystać z ubezpieczenia zdrowotnego w Polsce, czyli publicznej służby zdrowia. Poza tym okres zarejestrowania jako osoby bezrobotnej jest okresem składkowym uwzględnianym przy obliczaniu świadczeń emerytalnych. Sam fakt rejestracji cudzoziemca jako osoby bezrobotnej wiąże się więc z pewnymi możliwościami korzystania z instytucji opiekuńczych polskiego państwa.

Natomiast nie wszystkim zarejestrowanym bezrobotnym przysługuje zasiłek dla bezrobotnych. W celu uzyskania uprawnień do zasiłku dla bezrobotnych cudzoziemcy (wyłącznie kategorie cudzoziemców wymienione wcześniej) muszą spełnić ten sam dodatkowy warunek co obywatele polscy. Taka osoba powinna wykazać, że w okresie 18 miesięcy bezpośrednio poprzedzających dzień zarejestrowania, łącznie przez co najmniej rok była w Polsce zatrudniona i osiągała wynagrodzenie w kwocie co najmniej minimalnego wynagrodzenia za pracę. zarówno zatrudnienie etatowe, jak i inne (np. umowa cywilnoprawna). Do okresu rocznego zatrudnienia liczy się również fakt zatrudnienia za granicą w przypadku osób, które przybyły do Polski jako repatrianci. Prawo do zasiłku nie przysługuje cudzoziemcowi (jak i obywatelowi RP), jeśli odmówił - bez uzasadnionej przyczyny - przyjęcia zaproponowanej pracy zarobkowej, szkolenia, stażu, przygotowania zawodowego dorosłych, wykonywania prac interwencyjnych, robót publicznych lub nie podjął takiego szkolenia czy prac po skierowaniu.

Pewne ograniczenie dotyczy osób posiadających zezwolenie na pracę (inne niż praca na podstawie „niebieskiej karty” UE lub praca badawcza) lub zezwolenie na prace w zarządzie spółki. Są one uprawnione, po spełnieniu ustawowych warunków, do zasiłku dla bezrobotnych, ale już nie do innych świadczeń w postaci stypendiów i dodatków aktywizacyjnych.

\section{Imigranci zarejestrowani jako bezrobotni}

Imigranci zarejestrowani jako bezrobotni to przede wszystkim osoby w państw byłego Związku Radzieckiego. Główne kraje ich pochodzenia to Ukraina, Białoruś, Armenia, Rosja ${ }^{6}$. Wynika to między innymi z liczebności tych populacji: największą

${ }^{5}$ Art. 72 pziirp.

${ }^{6}$ Warto dodać, że podobne kraje pochodzenia bezrobotnych cudzoziemców wskazywano najczęściej podczas Narodowego Spisu Powszechnego (2002). Inaczej niż w tym artykule, w NSP określono osoby bezrobotne zgodnie z definicją BAEL-owską jako pozostające bez pracy, poszukujące zatrudnienia, zdolne do aktywności zawodowej (niekonieczne zarejestrowane w urzędzie pracy). Analiza przedstawiona przez GUS dotyczyła jedynie grupy imigrantów czasowych przebywających w Polsce powyżej 2 miesięcy. Najwięcej bezrobotnych było wśród Ukraińców (669), Białorusinów (180), Rosjan (170), Armeńczyków (89) (GUS 2003: 156). 
grupą imigrancką w Polsce są obecnie Ukraińcy, pozostałe wymienione państwa również są ważnymi krajami wysyłającymi. Warto również zwrócić uwagę, że do obywateli państw byłego Związku Radzieckiego adresowane są regulacje prawne umożliwiające migrację do Polski osób o polskim pochodzeniu (ustawa o Karcie Polaka), co również przyczynia się do wzrostu liczebności i znaczenia tych populacji. Zasady dowiedzenia polskiego pochodzenia są ujęte bardzo liberalnie, a otrzymanie Karty Polaka umożliwia uzyskanie stałego pobytu w Polsce od razu po przyjeździe. Ponadto wielkość populacji Rosjan zarejestrowanych jako bezrobotni należy wyjaśniać głównie obecnością uchodźców z Czeczenii (Czeczeńcy figurują w statystykach jako Rosjanie).

Zestawienie państw pochodzenia największych grup bezrobotnych imigrantów nie odzwierciedla jednak wprost wielkości strumieni migracyjnych do Polski. Przede wszystkim zwraca uwagę nieobecność Wietnamczyków, którzy są dużą społecznością w Polsce (10 269 osób o zarejestrowanym pobycie według danych UDSC ze stycznia 2017) oraz innych licznych społeczności azjatyckich, takich jak Chińczycy (7042 osoby) czy Indusi (4546 osoby). Wytłumaczeniem może być duża solidarność wewnątrzgrupowa w społeczności wietnamskiej. W ramach tej diaspory organizuje się samopomoc imigrantom $\mathrm{z}$ własnego kraju, znajdującym się $\mathrm{w}$ trudnej sytuacji ekonomicznej. Wiąże się to z kulturowo uwarunkowaną niechęcią do szukania pomocy socjalnej od państwa, dążeniem do rozwiązywania problemów ekonomicznych bez ingerencji ze strony instytucji kraju przyjmującego. Tłumacząc nieobecność tych grup imigranckich w zestawieniu najczęstszych krajów pochodzenia zarejestrowanych bezrobotnych, należy też podkreślić specyficzną strukturę migracji z Chin oraz Indii. Są to głównie przedsiębiorcy i studenci, również stąd wynika brak zarejestrowanych bezrobotnych.

W zestawieniu społeczności imigranckich o najwyższej liczbie zarejestrowanych bezrobotnych pojawiają się też cztery grupy z państw Unii Europejskiej, przy czym ważny wydaje się fakt, że trzy z nich to mniej rozwinięte gospodarczo państwa członkowskie, które przystąpiły do UE w 2004 r. lub później (Bułgaria, Litwa, Rumunia). Zgodnie z zasadami koordynacji systemów zabezpieczenia społecznego (możliwość eksportowania świadczeń), migranci wewnątrzunijni mogą pobierać zasiłek dla bezrobotnych w jednym z krajów członkowskich, ale jednocześnie rezydować i szukać zatrudnienia w innym kraju.

Kolejny wykres przedstawia imigrantów długotrwale bezrobotnych, czyli osoby zarejestrowane $\mathrm{w}$ urzędach pracy przez co najmniej 12 miesięcy na przestrzeni ostatnich dwóch lat. Bezrobocie długotrwałe prowadzi do atrofii społecznej, izolacji, pogorszenia zdrowia fizycznego i psychicznego (Kabaj 2001: 13-15). Taka trajektoria zawodowa, oznaczająca przedłużający się brak doświadczeń zarobkowych, utrudnia aktywizację na rynku pracy. Również w tej grupie dominują cudzoziemcy z Ukrainy, Rosji, Białorusi i Armenii. Długotrwale bezrobotni Ukraińcy stanowią $46,48 \%$ zarejestrowanych bezrobotnych z tego kraju. W przypadku 
Wykres 1 .

Imigranci zarejestrowani jako bezrobotni w Polsce - główne kraje pochodzenia (2017)

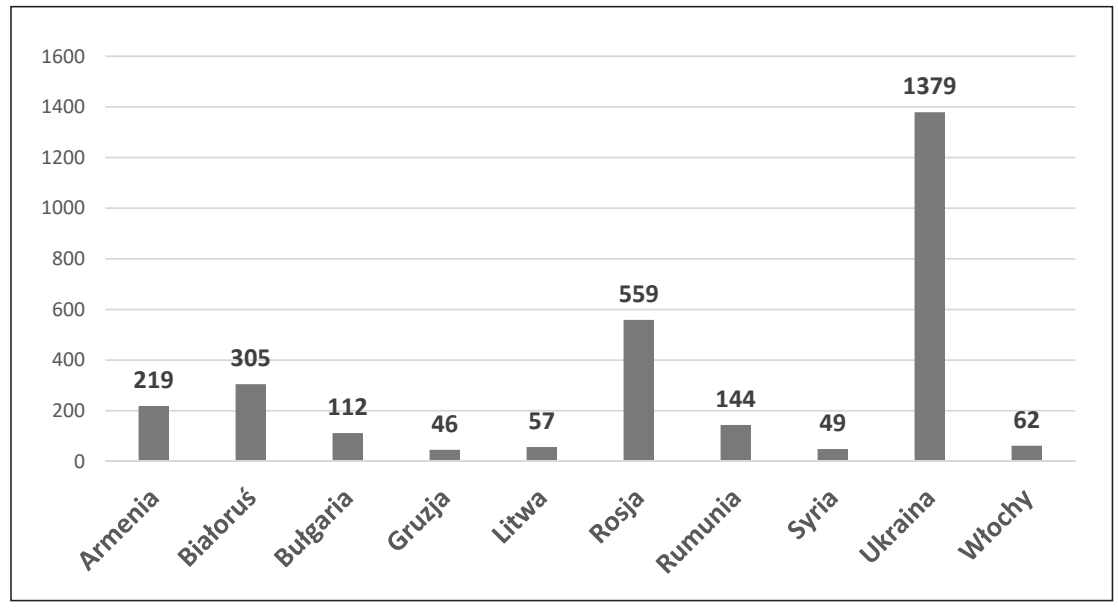

Źródło: opracowanie własne na podstawie danych Ministerstwa Rodziny, Pracy i Polityki Społecznej (IV 2017)

Wykres 2 .

Długotrwale bezrobotni imigranci w Polsce - 2017.

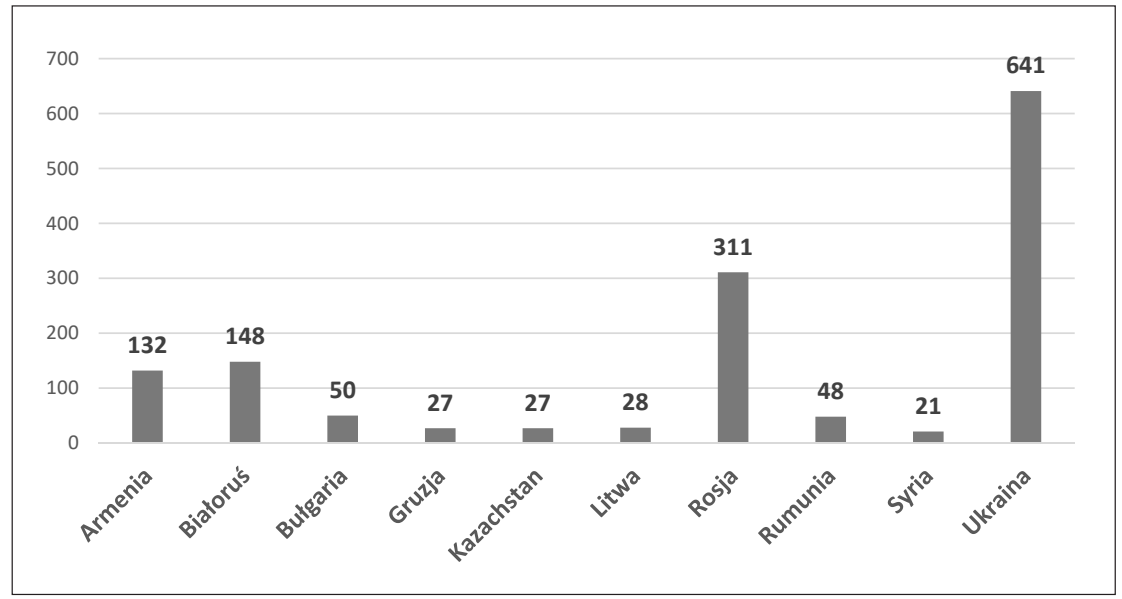

Źródło: opracowanie własne na podstawie danych Ministerstwa Rodziny, Pracy i Polityki Społecznej (IV 2017)

Rosji i Białorusi odsetek ten wynosi odpowiednio 55,64\% oraz 48,52\%. Te dane pokazują znacząco odmienny obraz bezrobocia długotrwałego wśród imigrantów niż w przypadku ludności rodzimej, gdzie udział bezrobotnych długotrwale w ogólnej populacji bezrobotnych wynosił w 2017 roku 22,9\% (GUS 2018: 37). 
Dostępne dane wskazują zatem, że bezrobotni imigranci są bardziej narażeni na ryzyko bezrobocia długotrwałego niż bezrobotna ludność rodzima. W przypadku zarejestrowanych bezrobotnych autochtonów powrót do aktywności zawodowej wydaje się bardziej prawdopodobny i zapewne łatwiejszy niż wyjście z bezrobocia w przypadku cudzoziemców.

Najliczniejszą grupą cudzoziemców zarejestrowanych jako bezrobotni są Ukraińcy. W okresie 2010-2017 liczba Ukraińców rejestrujących się w urzędach pracy zwiększyła o 36,4\%. Wynika to z dynamicznego wzrostu populacji Ukraińców, co pokazane jest w dalszej części analizy. Liczba Ukraińców zarejestrowanych jako bezrobotni rosła najbardziej dynamicznie w okresie od 2010 do 2013, a w kolejnych latach ustabilizowała się na obecnym poziomie. Ten trend jest wart podkreślenia w kontekście faktu, że między 2010 a 2013 r. liczba Ukraińców w Polsce wzrosła o niespełna 10 tysięcy osób (z 28 tysięcy do 37 tysięcy). Tymczasem w kolejnym okresie, w latach od 2013 do 2017, liczebność społeczności ukraińskiej - uwzględniając migrantów zarejestrowanych - wzrosła niemal trzykrotnie, o ponad 60 tysięcy (z 37 tysięcy do ponad 103 tysięcy). Odpowiednie dane ilustrujące to zjawisko prezentuje Tabela 2, przedstawiona $\mathrm{w}$ dalszej części artykułu. Obecnie przyrost liczby bezrobotnych Ukraińców jest mniej dynamiczny niż przyrost liczby imigrantów z Ukrainy w ogóle.

Wykres 3 .

Ukraińcy zarejestrowani jako bezrobotni w Polsce (2010-2017)

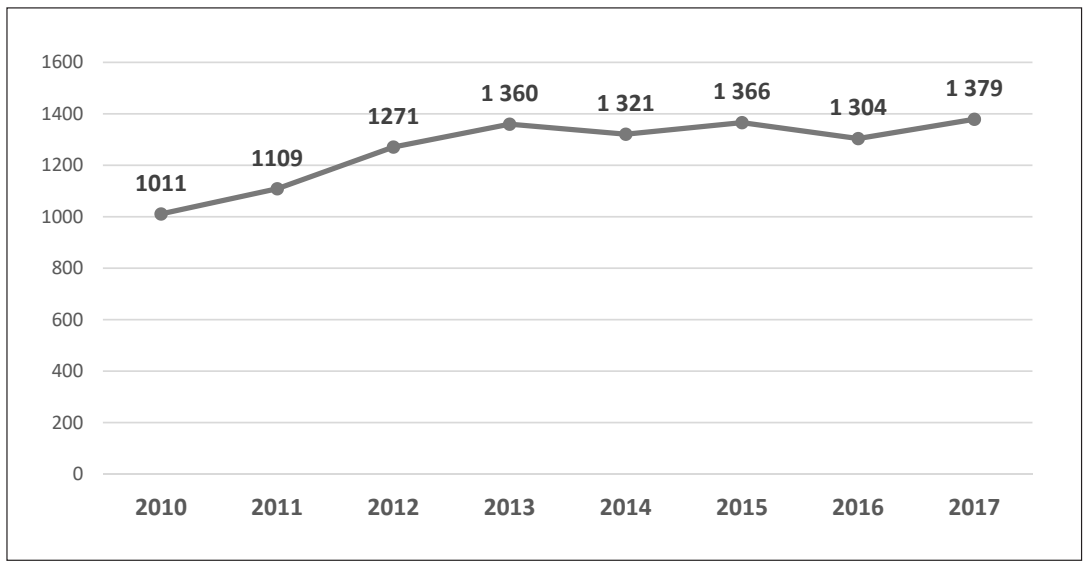

Źródło: opracowanie własne na podstawie danych Ministerstwa Rodziny, Pracy i Polityki Społecznej (IV 2017)

Geograficzne rozlokowanie rejestracji statusu bezrobotnego wśród cudzoziemców odpowiada przestrzennym wzorom zamieszkiwania społeczności imigranckich. W obu przypadkach główną rolę odgrywa województwo mazowieckie. W 2017 r. najwięcej zarejestrowanych bezrobotnych imigrantów mieszkało właśnie 
w tym województwie (1113 osób, w tym 379 osób z Ukrainy). Na kolejnych miejscach są województwa lubelskie (419 osób) oraz podlaskie (335 osób). Widoczne jest jednak pewne zróżnicowanie dotyczące poszczególnych społeczności imigranckich w określonych województwach, co wynika zapewne $\mathrm{z}$ ich przygranicznego charakteru (np. w województwie podkarpackim jest tylko 162 zarejestrowanych bezrobotnych cudzoziemców, ale aż 107 z nich to Ukraińcy).

\section{Imigranci z prawem do zasiłku dla bezrobotnych}

Wśród cudzoziemców zarejestrowanych jako bezrobotni dość niewielu ma także uprawnienia do pobierania zasiłku dla bezrobotnych. Zarejestrowani bezrobotni nie mogą otrzymywać zasiłku w szeregu przypadków wymienionych w ustawie o promocji zatrudnienia i instytucjach rynku pracy, m.in. jeśli zgłosili się do urzędu pracy w okresie zawieszenia wykonywania działalności gospodarczej. Osoba bez pracy nie może uzyskać zasiłku, jeśli pobiera inne świadczenia przysługujące zarejestrowanym bezrobotnym, takie jak stypendia na szkolenia albo świadczenie z tytułu odbywania odpłatnej praktyki absolwenckiej.

Podobnie jak w przypadku zarejestrowanych bezrobotnych, wśród cudzoziemców z prawem do pobierania zasiłku najwięcej jest osób z państw byłego Związku Radzieckiego. Pierwsze miejsce w zestawieniu zajmują obywatele Ukrainy. Kolejne najpopularniejsze kraje pochodzenia to Rosja i Białoruś. Jednak liczby osób uprawnionych do zasiłku są minimalne. Przedstawione zestawienie dowodzi, że jest to zjawisko absolutnie marginalne.

Wykres 4 .

Imigranci z prawem do zasiłku dla bezrobotnych - główne kraje pochodzenia (2017)

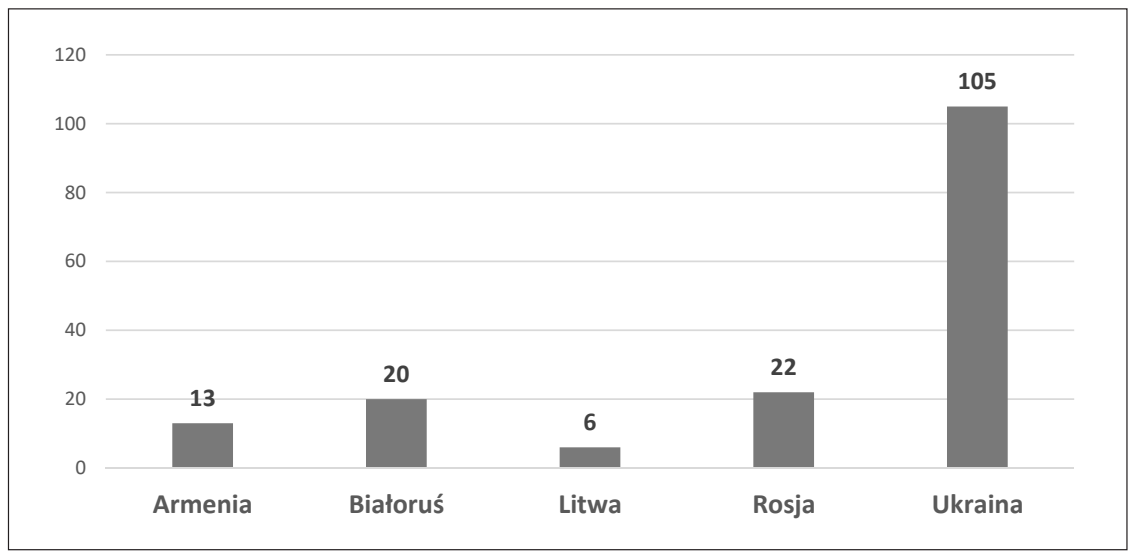

Źródło: opracowanie własne na podstawie danych Ministerstwa Rodziny, Pracy i Polityki Społecznej (IV 2017) 
Analogicznie jak w przypadku zarejestrowanych bezrobotnych cudzoziemców, najliczniejszą grupą pobierającą zasiłki dla bezrobotnych są Ukraińcy. Jest to jednak bardzo niewielka grupa imigrantów z tej społeczności - około 100 osób rocznie. W badanym okresie (2010-2017) liczba Ukraińców pobierających zasiłki dla bezrobotnych utrzymywała się cały czas na podobnym poziomie. Wahania wynosiły kilka lub kilkanaście osób rocznie. W tym samym okresie liczba Ukraińców mieszkających w Polsce i mających formalnie prawo do rejestracji w urzędzie pracy $\mathrm{w}$ razie utraty pracy zdecydowanie się zwiększyła.

Wykres 5 .

Imigranci z Ukrainy z prawem do zasiłku dla bezrobotnych

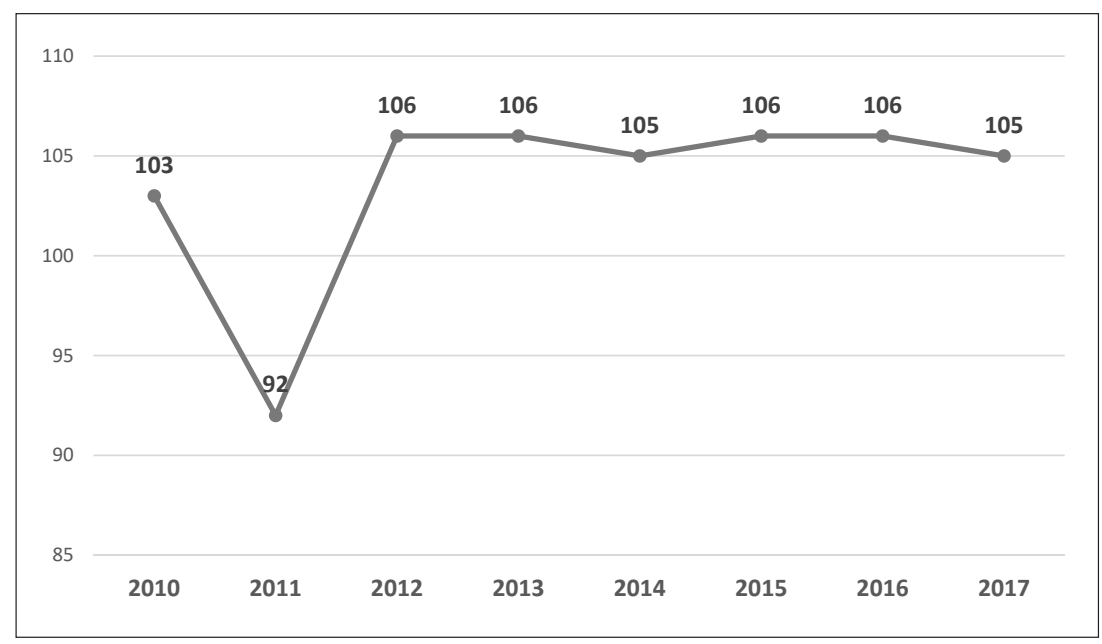

Źródło: opracowanie własne na podstawie danych Ministerstwa Rodziny, Pracy i Polityki Społecznej (IV 2017)

Z uwagi na to, że liczba cudzoziemców pobierających zasiłki jest minimalna, kolejne analizy w tym artykule skupią się na grupach imigranckich, które zostały wskazane na Wykresie 1 jako społeczności o największej liczbie zarejestrowanych bezrobotnych. Są to obywatele: Ukrainy Rosji, Białorusi, Armenii, Rumunii, Bułgarii, Włoch, Syrii, Gruzji, Litwy.

Według danych GUS (2017) w Polsce 14\% bezrobotnych ma prawo do pobierania zasiłku (w 2016 r. - 13\%). W społecznościach imigranckich ten odsetek jest znacznie niższy. W przypadku niektórych grup imigrantów (Gruzja, Syria) nikt z zarejestrowanych osób nie miał prawa do pobierania zasiłku. W największej pod względem liczby bezrobotnych, jak i ogólnej liczebności społeczności Ukraińców odsetek osób z prawem do zasiłku wynosi nieco ponad 8\%. To pokazuje, że nawet zarejestrowani w urzędach pracy imigranci korzystają ze świadczeń społecznych w mniejszym zakresie niż ludność rodzima. 
Tabela 1 .

Udział osób z prawem do zasiłku w populacji cudzoziemców zarejestrowanych jako bezrobotni

\begin{tabular}{|c|c|c|c|}
\hline Obywatelstwo & $\begin{array}{c}\text { Liczba } \\
\text { zarejestrowanych } \\
\text { bezrobotnych }(2016)\end{array}$ & $\begin{array}{c}\text { Liczba bezrobotnych } \\
\text { z prawem do zasiłku } \\
(2016)\end{array}$ & $\begin{array}{c}\text { Odsetek } \\
\text { bezrobotnych } \\
\text { z prawem do } \\
\text { zasiłku wśród } \\
\text { zarejestrowanych } \\
\text { bezrobotnych }\end{array}$ \\
\hline Armenia & 213 & 12 & $5,63 \%$ \\
\hline Białoruś & 284 & 23 & $8,1 \%$ \\
\hline Bułgaria & 88 & 7 & $7,95 \%$ \\
\hline Gruzja & 40 & 0 & $0 \%$ \\
\hline Litwa & 53 & 4 & $7,55 \%$ \\
\hline Rosja & 527 & 20 & $3,8 \%$ \\
\hline Rumunia & 117 & 3 & $2,56 \%$ \\
\hline Syria & 53 & 0 & $0 \%$ \\
\hline Ukraina & 1304 & 106 & $8,13 \%$ \\
\hline Włochy & 55 & 8 & $14,55 \%$ \\
\hline Wietnam & 14 & 1 & $7,14 \%$ \\
\hline Indie & 19 & 0 & $0 \%$ \\
\hline Chiny & 7 & 1 & $14,29 \%$ \\
\hline
\end{tabular}

Źródło: Opracowanie własne na podstawie danych MRPiPS

Zwraca uwagę bardzo niska liczba zarejestrowanych bezrobotnych z Wietna$\mathrm{mu}$, Indii oraz Chin. W przypadku tych krajów tylko pojedyncze osoby pobierały w 2016 r. zasiłek dla bezrobotnych (wśród imigrantów z Indii - nikt).

\section{Dynamika bezrobocia w kontekście zmian liczebności grup imigranckich}

W przypadku populacji imigranckich nie jest możliwe dokładne obliczenie stopy bezrobocia poszczególnych grup narodowych. Dane statystyczne umożliwiają jednak prześledzenie populacji imigranckich z podziałem na tytuły pobytowe. Takie tytuły pobytowe, jak stały pobyt czy pobyt czasowy, mogą otrzymać zarówno osoby aktywne zawodowo, jak i nieaktywne zawodowo. Nie przy wszystkich kategoriach można zatem mówić o bezrobociu. Nawet wyodrębniając określone 
statusy pobytowe należy pamiętać, że mogą je otrzymać również studenci i osoby niepełnoletnie. Dlatego konieczne jest zastrzeżenie, że dane na temat liczby cudzoziemców, którzy spełniają warunki, aby w przypadku utraty pracy uzyskać możliwość rejestracji jako bezrobotni oraz otrzymania zasiłku, są jedynie przybliżone. Wskazane tytuły pobytowe obejmują bowiem nie tylko osoby wliczane do zasobu siły roboczej, ale także studentów, dzieci, osoby celowo rezygnujące z pracy z powodu zajmowania się gospodarstwem domowym (np. opiekujące się dziećmi lub starszymi członkami rodziny). Nie istnieje możliwość wyodrębnienia w tej grupie wyłącznie osób aktywnych zawodowo.

Tabela 2 prezentuje liczbę imigrantów z państw trzecich posiadających tytuły pobytowe potencjalnie „dopuszczające” przejście do statusu bezrobotnego w kraju przyjmującym ${ }^{7}$. Zestawienie za lata 2015-2017 uwzględnia imigrantów posiadających zezwolenie na pobyt stały, zezwolenie na pobyt rezydenta długoterminowego UE, zezwolenie na pobyt czasowy, pobyt czasowy i pobyt stały członka rodziny obywatela UE, status uchodźcy, ochronę uzupełniającą, pobyt tolerowany, pobyt ze względów humanitarnych. Zestawienia z lat 2012-2013 (przed wejściem w życie nowej ustawy o cudzoziemcach, która zmieniła nazewnictwo i zasady otrzymywania tytułów pobytowych) uwzględniają imigrantów posiadających zezwolenie na osiedlenie się, status rezydenta długoterminowego UE, pobyt tolerowany, status uchodźcy, ochronę uzupełniającą, zezwolenie na zamieszkanie na czas oznaczony.

Kolejna tabela przedstawia proporcję osób bezrobotnych do tak obliczonej populacji imigranckiej danego kraju. Punktem odniesienia i kontekstem porównawczym dla analizy tych danych będzie stopa bezrobocia w Polsce, ujmowana jako stosunek liczby zarejestrowanych bezrobotnych do całej aktywnej populacji kraju. Stopa bezrobocia w Polsce w 2017 r. (miesiąc kwiecień) wyniosła 7,6\% była najniższa od lat dziewięćdziesiątych XX w. Z kolei w 2012 r. wynosiła 12,9\%. Na przestrzeni lat obserwuje się zdecydowany spadek stopy bezrobocia w Polsce.

7 W zestawieniu nie uwzględniono osób przybywających na podstawie oświadczenia o powierzeniu pracy cudzoziemcowi. System ten jest skierowany do obywateli Ukrainy, Rosji, Białorusi, Mołdawii, Armenii, Gruzji. Umożliwia wykonywanie pracy przez maksimum 6 miesięcy, w ciągu kolejnych 12 miesięcy. Pominięcie osób przybywających na podstawie systemu oświadczeń wynika z faktu, że - przez samą krótkotrwałość ich pobytu, a także obowiązek wyjazdu w wypadku utraty pracy - nie mogą oni być objęci systemem ochrony przed bezrobociem. Niemożliwe jest też obliczenie liczby migrantów sezonowych przybywających w ramach procedury oświadczeń. Nie wszyscy, którzy otrzymują oświadczenie, przybywają do Polski, poza tym niektórzy posiadają kilka oświadczeń jednocześnie. Tym niemniej należy podkreślić, że uwzględnienie „oświadczeniowców” w populacji imigrantów (w przypadku samych Ukraińców to około miliona osób rocznie) spowodowałoby, że obliczona w ten sposób „stopa bezrobocia” wśród migrantów z państw byłego ZSRR byłaby znacznie niższa i zamykałaby się w liczbie poniżej $1 \%$.

Od 2018 r. system oświadczeń jest stopniowo zastępowany systemem rekrutacji do prac sezonowych, wynikającym z wdrażania dyrektywy sezonowej UE do polskiego porządku prawnego (dyrektywa Parlamentu Europejskiego i Rady 2014/36/UE z 26 II 2014 r. w sprawie warunków wjazdu i pobytu obywateli państw trzecich w celu zatrudnienia w charakterze pracownika sezonowego). 
Tabela 2 .

Liczba cudzoziemców z wybranych krajów trzecich posiadających tytuły pobytowe w Polsce

(2012-2017)

\begin{tabular}{|l|r|r|r|r|r|}
\hline Kraj pochodzenia & XII 2012 & XII 2013 & I 2015 & I 2016 & I 2017 \\
\hline Armenia & 4587 & 4842 & 3586 & 3817 & 3516 \\
\hline Białoruś & 10310 & 11160 & 9924 & 11172 & 11428 \\
\hline Gruzja & 539 & 635 & 651 & 892 & 1188 \\
\hline Rosja & 12363 & 12645 & 10739 & 9972 & 10583 \\
\hline Syria & 602 & 773 & 798 & 832 & 964 \\
\hline Ukraina & 34303 & 37679 & 40979 & 65866 & 103457 \\
\hline
\end{tabular}

Z metodologicznego punktu widzenia (z przyczyn wskazanych powyżej) nie można w analogicznych sposób wskazać stopy bezrobocia w populacjach imigranckich. Jednak na podstawie dostępnych danych możliwe jest obliczenie odsetka bezrobotnych w populacji imigrantów o tytułach pobytowych uprawniających do dłuższego pobytu i korzystania z określonych świadczeń, takich jak ubezpieczenie zdrowotne bezrobotnych oraz zasiłek. Tabela 3 pokazuje wyraźnie, że odsetek bezrobotnych zmniejszał się na przestrzeni lat (2012-2017) w większości badanych społeczności imigranckich. Można zatem wysnuć z dużym prawdopodobieństwem wniosek, że również stopa bezrobocia wśród imigrantów zmniejszała się w badanym okresie. Odsetek bezrobotnych w badanych społecznościach imigranckich jest znacznie niższy niż stopa bezrobocia w Polsce.

Najwyższy odsetek zarejestrowanych bezrobotnych, według danych z 2017 r., jest w społeczności armeńskiej i rosyjskiej. Jednak nawet w tych grupach pozostaje on znacznie niższy niż stopa bezrobocia w Polsce. Zwraca uwagę przypadek Ukraińców, którzy są grupą cudzoziemców z największą liczbą zarejestrowanych bezrobotnych i największą liczbą pobierających zasiłek w Polsce. W porównaniu z rokiem 2012, odsetek bezrobotnych w tej społeczności imigranckiej zdecydowanie zmalał. Jeśli porównamy liczbę zarejestrowanych bezrobotnych z Ukrainy do wielkości całej ukraińskiej populacji w Polsce, to w 2012 odsetek bezrobotnych wyniósł 3,71\%, natomiast w 2017 odsetek bezrobotnych wyniósł zaledwie 1,33\%. Chociaż liczba bezwzględna Ukraińców zarejestrowanych jako bezrobotni rośnie, to odsetek bezrobotnych w społeczności ukraińskiej spada. Przyrost populacji imigranckiej jest znacznie większy niż przyrost bezrobotnych w tej populacji.

Dane z pierwszego półrocza 2017 r. potwierdzają również wyjątkowo niski odsetek bezrobocia rejestrowanego w społecznościach wietnamskiej, chińskiej oraz hinduskiej. W populacji imigrantów z Wietnamu udział bezrobotnych wyniósł $0,13 \%$ (15 zarejestrowanych bezrobotnych na 11403 cudzoziemców 
z uregulowanym pobytem). W populacji imigrantów z Indii wyniósł $0,41 \%$ (24 osoby bezrobotne, 5838 osób z tytułami pobytowymi). W społeczności chińskiej odsetek ten był równy 0,07\% (6 bezrobotnych cudzoziemców, 8063 cudzoziemców z tytułami pobytowymi).

Tabela 3 .

Nasilenie zjawiska bezrobocia w wybranych społecznościach imigranckich

\begin{tabular}{|c|c|c|c|c|c|c|}
\hline obywatelstwo & $\begin{array}{c}\text { bezro- } \\
\text { botni } \\
2012\end{array}$ & $\begin{array}{l}\text { odsetek bez- } \\
\text { robotnych } \\
\text { w populacji } \\
\text { migrantów } \\
2012^{*}\end{array}$ & $\begin{array}{c}\text { bezro- } \\
\text { botni } \\
2016\end{array}$ & $\begin{array}{l}\text { odsetek bez- } \\
\text { robotnych } \\
\text { w populacji } \\
\text { migrantów } \\
2016^{*}\end{array}$ & $\begin{array}{c}\text { bezro- } \\
\text { botni } \\
2017\end{array}$ & $\begin{array}{c}\text { odsetek bez- } \\
\text { robotnych } \\
\text { w populacji } \\
\text { migrantów } \\
2017\end{array}$ \\
\hline Armenia & 228 & $4,97 \%$ & 213 & $5,59 \%$ & 219 & $6,22 \%$ \\
\hline Białoruś & 361 & $3,5 \%$ & 284 & $2,54 \% /$ & 305 & $2,67 \%$ \\
\hline Gruzja & 18 & $3,34 \%$ & 40 & $4,48 \%$ & 46 & $3,87 \%$ \\
\hline Rosja & 695 & $5,62 \%$ & 527 & $5,28 \%$ & 559 & $5,28 \%$ \\
\hline Syria & 14 & $2,33 \%$ & 53 & $6,37 \%$ & 49 & $5,08 \%$ \\
\hline Ukraina & 1271 & $3,71 \%$ & 1304 & $1,98 \%$ & 1379 & $1,33 \%$ \\
\hline
\end{tabular}

* Bez uwzględnienia migrantów sezonowych, przybywających tylko do pracy i wyjeżdżających po jej wykonaniu. Jak wskazano wyżej, tytuły pobytowe („ogół populacji migrantów”) obejmują nie tylko osoby wliczane do zasobu siły roboczej, ale także studentów, dzieci, osoby celowo rezygnujące z pracy.

Źródło: Opracowanie własne na podstawie danych MRPiPS i UDSC

Dane o charakterze urzędowym nie dostarczają informacji o tym, jaki odsetek cudzoziemców pracuje w szarej strefie. Mogą to być zarówno osoby zarejestrowane jako bezrobotne, jak też cudzoziemcy nie dokonujący takiej rejestracji. Jednak podejmowanie aktywności zarobkowych w szarej strefie jest raczej domeną imigrantów przebywających w kraju przyjmującym nielegalnie (por. Dąbrowski 2014), a tymczasem przytaczane statystyki dotyczą osób przebywających legalnie i posiadających tytuły pobytowe.

\section{Podsumowanie}

Dane urzędowe pokazują, że bezrobocie wśród cudzoziemców w Polsce jest niskie. Pozostaje poniżej stopy bezrobocia ogółu populacji kraju. Wskazując przyczyny takiego stanu rzeczy, warto podkreślić kilka czynników. Niewielkie bezrobocie wśród imigrantów niekoniecznie wynika $\mathrm{z}$ faktu, że po utracie pracy chcą wracać do kraju pochodzenia lub szukają tam zatrudnienia. W grę wchodzą też inne 
aspekty. Pierwszy z nich określić można jako sektorowy. W branżach, w których szczególnie często zatrudniani są cudzoziemcy (np. budownictwo, rolnictwo i sadownictwo, gastronomia, handel) pracownicy są poszukiwani, łatwo znaleźć pracę, a nawet ją zmienić, gdy zaistnieje taka konieczność. Drugi aspekt można określić jako obniżone wymagania dotyczące zatrudnienia. Imigranci są gotowi podejmować aktywności zarobkowe dostępne na polskim rynku pracy, nawet cechujące się niskim prestiżem, niewielkimi płacami i poniżej ich kwalifikacji zawodowych. Po trzecie, wchodzi w grę prawdopodobnie poszukiwanie pracy kanałami pozaoficjalnymi. Osoby bez pracy poszukują jej aktywnie i samodzielnie, albo z pomocą sieci społecznych (wykorzystując etniczny kapitał społeczny). Wynikać to może z nieufności wobec instytucji państwa przyjmującego, obawy przed koniecznością opuszczenia kraju, a nawet nieznajomości swoich praw jako osób bezrobotnych ${ }^{8}$. Po czwarte, różne wzory pobierania świadczeń społecznych przez Polaków i cudzoziemców mogą wiązać się ze zróżnicowanymi konsekwencjami działań nielegalnych. Niektórzy Polacy rejestrują się jako bezrobotni i pobierają zasiłek, mając przy tym inne źródła dochodów i zajmując się aktywnościami w szarej strefie. Imigranci są prawdopodobnie mniej skłonni do takich zachowań, ponieważ w ich przypadku są one obarczone większym ryzykiem, grozi za to wydalenie z kraju pobytu. Oczywiście niektórzy imigranci są aktywni zarobkowo w szarej strefie. Co prawda aktywność taka nie wyklucza rejestracji jako osoba bezrobotna, ale pobieranie zasiłku przez osoby pracujące wiąże się z popełnieniem przestępstwa i ryzykiem skazania przez sąd karny. Praca w szarej strefie, choć nielegalna, jest społecznie akceptowana, jednak pobieranie świadczeń społecznych dla bezrobotnych przez osoby faktycznie pracujące zarobkowo jest sankcjonowane ostrzej. (Należy zaznaczyć, że analizowane tu dane statystyczne nie przesądzają o tym, czy imigranci zarejestrowani jako bezrobotni pracują w szarej strefie.)

W krajach, w których bezrobocie grup etnicznych jest wysokie (np. Niemcy, mniejszość turecka), żyje obecnie drugie lub trzecie pokolenie ludności napływowej. Problemy społeczne związane z dezaktywizacją zawodową mniejszości etnicznych są tam wynikiem zaniedbanej polityki integracyjnej wobec pierwszego pokolenia migrantów zarobkowych i międzypokoleniowej transmisji niskiego statusu społeczno-ekonomicznego. To pokazuje, że brak efektywnej polityki integrowania cudzoziemców - i oczekiwanie, że wrócą oni do kraju pochodzenia - może mieć negatywny wpływ na przyszłe trendy. Może to być również lekcja dla Polski. Przedstawione dane wskazują, że obecnie świadczenia społeczne oferowane przez polskie państwo opiekuńcze nie mają dużego znaczenia dla imigrantów. Pobór świadczeń dla bezrobotnych jest znikomy, toteż zasadny wydaje się wniosek, że nie

8 Taki wątek pojawił się już we wcześniejszym badaniu, które prowadziłam wśród przedsiębiorców ukraińskich w Polsce: jedna z respondentek, która legitymowała się stałym pobytem, była przekonana że grozi jej wydalenie z Polski, jeśli zamknie działalność gospodarczą i nie będzie nigdzie zatrudniona. 
kształtują one strategii migracyjnych cudzoziemców, ani nie stanowią „magnesu” przyciągającego do Polski. Instrumenty polityki społecznej takie jak zasiłki dla osób bez pracy mają pewne znaczenie głównie dla imigrantów długoterminowych i osiedleńczych - uprawnionych do korzystania z instytucji państwa opiekuńczego. Wyraźnie rysuje się jednak odrębność wzorów korzystania ze wsparcia państwa przez ludność napływową (mniejszy odsetek bezrobotnych z prawem do zasiłku niż w społeczeństwie przyjmującym, większy udział długotrwale bezrobotnych w populacji osób bez pracy).

\section{Literatura}

Błędowski P. (2013), Aktywność zawodowa osób w starszym wieku, w: Marta Kiełkowska (red.), Rynek pracy wobec zmian demograficznych, Warszawa: Instytut Obywatelski, 52-63.

Borjas G. J. (1999), Immigration and Welfare Magnets, „Journal of Labor Economics”, vol. 17, no. 4 , pt. $1,607-637$.

Danecka M. (2005), Bezrobocie i instytucje rynku pracy, Warszawa: ISP PAN.

Dąbrowski P. (2014), Praca przymusowa cudzoziemców w Polsce. Analiza zjawiska w wybranych grupach imigranckich, Warszawa: Wydawnictwa Uniwersytetu Warszawskiego.

Deacon B. (2000), Eastern European welfare states: the impact of the politics of globalization, „Journal of European Social Policy", vol. 10 (2), 146-161.

Dolny E., Wiśniewski Z., Wojdyło-Preisner M. (2014), Długotrwałe bezrobocie w Polsce, w: Z. Wiśniewski, M. Wojdyło-Preisner (red.), Diagnozowanie stopnia zagrożenia długotrwałym bezrobociem. Teoria i praktyka, Warszawa, 11-20.

Duszczyk M., Żołędowski C. (2016), Polityka społeczna a migracje, w: A. Górny, P. Kaczmarczyk, M. Lesińska (red.), Transformacje. Przewodnik po zmianach społeczno-ekonomicznych $w$ Polsce, Warszawa: Scholar, 286-292.

Esping-Andersen G. (2010), Trzy światy kapitalistycznego państwa dobrobytu, Warszawa: Diffin.

Fenger H.J.M. (2007), Welfare regimes in Central and Eastern Europe: Incorporating post-communist countries in a welfare regime typology, „Contemporary Issues and Ideas in Social Sciences", Vol. 3, No 2.

Corrado G., Guzi M., Kahanec M., Zimmermann K.F. (2013), Unemployment benefits and immigration: evidence from the EU, „International Journal of Manpower”, Vol. 34 Issue 1, 24-38.

Hammarstedt M. (2009), Assimilation and participation in social assistance among immigrants, „International Journal of Social Welfare", Vol. 18, Issue 1, 85-94.

Handlos L. N., Kristiansen M., Norredam M. (2016), Wellbeing or welfare benefits - what are the drivers for migration?, „Scandinavian Journal of Public Health”, vol. 44, 117-119.

Janukowicz P. (2010), Bezrobocie rejestrowane a bezrobocie według BAEL, „Polityka Społeczna” nr 1, 18-20.

Jędrzejczyk-Kuliniak K. (2017), Wymiary antagonizowania się kultur. Sekurytyzacja kryzysu migracyjnego, „Multicultural Studies” 2, 13-27.

Kabaj M. (2001), System aktywizacji długotrwale bezrobotnych. Synteza i wnioski z badań, w: Kabaj M. (red.), Badanie bezrobocia dtugotrwałego, Warszawa, 9-37.

Kabaj M. (2005), Ekonomia tworzenia i likwidacja miejsc pracy. Dezaktywizacja Polski?, Warszawa: Instytut Pracy i Spraw Socjalnych.

Kaczmarczyk P. (2015), Burden or Relief? Fiscal Impacts of Recent Ukrainian Migration to Poland, IZA DP No. 8779, January, Bonn. 
Klimek D. (2015), Funkcja ekonomiczna migracji zarobkowej z Ukrainy do Polski, Łódź: Wydawnictwo Politechniki Łódzkiej.

Piechota S. (2013), Zatrudnienie osób niepełnosprawnych w Polsce - potrzeby, bariery, możliwości, w: Kiełkowska M. (red.), Rynek pracy wobec zmian demograficznych, Warszawa: Instytut Obywatelski, 94-113.

Pilc M. (2014), Determinanty bezrobocia w Polsce w latach 1993-2012, Warszawa: Wydawnictwo CeDeWu.

Williams M. C. (2003), Words, Images, Enemies: Securitization and International Politics, „International Studies Quarterly”, vol. 47, Issue 4, 511-531.

Dane urzędowe:

Ministerstwo Rodziny, Pracy i Polityki Społecznej, dane udostępnione na potrzeby badania

Urząd do Spraw Cudzoziemców, https://udsc.gov.pl/statystyki/raporty-okresowe/zestawienia-roczne/

Główny Urząd Statystyczny (2003), Migracje zagraniczne ludności 2002, Warszawa (autorzy opracowania Zofia Kostrzewa, Joanna Stańczak, Paweł Kaczorowski)

Główny Urząd Statystyczny, dane o bezrobociu rejestrowanym http://stat.gov.pl/obszary-tematyczne/rynek-pracy/bezrobocie-rejestrowane/

Główny Urząd Statystyczny (2018), Aktywność ekonomiczna ludności Polski. Trzeci kwartał 2017, Warszawa. https://stat.gov.pl/obszary-tematyczne/rynek-pracy/pracujacy-bezrobotni-bierni-zawodowo-wg-bael/aktywnosc-ekonomiczna-ludnosci-polski-iii-kwartal-2017-roku,4,27.html 